\title{
CALCA Gene Product
}

National Cancer Institute

\section{Source}

National Cancer Institute. CALCA Gene Product. NCI Thesaurus. Code C136376.

A protein encoded by the CALCA gene. 